\title{
Spatial Analysis of Sustainable Land Use Development Coastal Areas in Batang Regency
}

\author{
Ahmad Ibnu Riza ${ }^{1}$ \\ Universitas Selamat Sri Batang, Central Java - Indonesia \\ Athoillah Islamy ${ }^{2}$ \\ Institut Agama Islam Negeri Pekalongan, Central Java - Indonesia
}

\begin{abstract}
Batang Regency as the northern coastal area of Java islandexperiences a problem of land use management that has not been optimal so that there is a need for analysis of land use development in the coastal area of Batang Regency. The purpose of this study is to examine the direction of land use development in coastal areas of Batang Regency with spatial analysis. This research method implementsquantitative approach while the analytical techniqueis spatial analysis. Spatial analysis is performed to identify land use of thecoastal area in Batang Regency. The study scope of coastal areasis based on administrative subdistricts located along the coast of Batang Regency. This research utilizes Spot satellite image year 2015 with the map of regionalspatial pattern plan of Batang Regency in 20112031. The spatial analysis result of land use developmentinBatang Regency's coastal area includes the suitable category of $18.130,65(56,32 \%)$ while the unsuitable category is $14.059,44,(43,68 \%)$. Batang Sub-district's suitable category is $1.214,03$ ha, while the unsuitable category is $2.220,51$ ha. Kandeman Sub-district's suitable category is 1.565 .02 ha, while the unsuitable category is $2.610,65$ ha. TulisSub-district'ssuitablecategory is $2.452,98$ ha, while the unsuitable category is $2.055,80$ ha. Subah Sub-district'ssuitablecategory is $5.381,89$ ha, while the unsuitable category is $2.970,28$ ha. Banyuputih Sub-district's suitable category is $2.314,61$ ha, while the unsuitable category is $2.127,89$ ha. Gringsing Subdistrict's suitablecategory is 5.202,12 ha, while the unsuitable categoryis $2.074,31$ ha. The conclusion of land use planning development for Batang and Kandeman Sub-districts is that there are still a lot of lands designated for residential development. Subah Sub-district is for fisheries development while Tulis, Banyuputih, and Gringsing Sub-districts are for industrial development.
\end{abstract}

Keywords: Land use, Batang Regency, Coastal area, Spatial pattern

\footnotetext{
${ }^{1}$ Ahmad Ibnu Riza is a lecturer at Selamat Sri Batang University, Batang, Central Java, Indonesia. E-mail: riza.ibnu.ahmad@gmail.com

${ }^{2}$ Athoillah Islamy is a lecturer at the Pekalongan State Islamic Institute, Central Java, Indonesia. E-mail: athoillahislamy@yahoo.co.id
} 


\title{
Spatial Analysis Of Sustainable Land Use Development Coastal Areas In Batanng Regency
}

\author{
Ahmad Ibnu Riza dan Athoillah Islamy
}

\section{Introduction}

Coastal areas and small islands are ideal areas in carrying out development planning in Indonesia. According to Bramati (2014), coastal areas attract a variety of interests and activities in limited space and for some unique and more complex reasons than inland areas. The coastal areas and small islands are not only exploited for their natural resources but also become the development areas for several development activities such as transportation and ports, industries, fisheries, tourism and settlements (Bengen, 2010). The law of the Republic of Indonesia No. 1 of 2014 states that the Management of Coastal Zone and Small Islands is a coordination of planning, utilization, supervision and control of coastal resources and small islands conducted by the Government and Local Government, between sectors, between ecosystems land and sea, and between science and management to improve people's welfare.

According to Dahuri (2003), an estimated $60 \%$ of the total population in Indonesia live in coastal areas. It is not surprising that coastal areas are the most populous areas inhabited by humans with a variety of development activities. BatangRegency is one of the regencies in the northern coastal area of Java Island that has a tendency to be developed as an integrated and sustainable coastal management area. With a coastline length of about $38.75 \mathrm{Km}$ stretches from east to west, there are many natural resources with the varying geographical conditions of Batang Regency such as coastal areas, lowland and highlands. Thefuture development of Batang Regency needs the optimization of coastal area management. The direction of development in BatangRegencyutilizes the coastal space that has been issued in the Regional Regulation no. 07 of 2011 on Spatial Plan of Batang Regency Year 2011-2031. For the direction of coastal area management planning, Regulation of Regent No. 16 of 2011 has been issued on the strategic plan of Coastal Area of Batang Regency in 2011-2030. Management of land use in the coastal areas can be performed by utilizing spatial data both raster data and vector data. According to Burrough (1986), Geographic Information System (GIS) is an integrated information systembecause the managed data is spatial data.

The nonoptimalmanagement of coastal areas inBatang Regency has disrupted the continuous management. Thissituation may arise due to various problems such as (1) Spatial use conflicts and (2) Unorganized coastal areas planning. According to Riza (2016), the development of coastal areas inBatangRegency is still not optimal due to the lack of support regardinggood policies and activities in the management of coastal areas. In addition to environmental factors, the reduction of mangrove plants along the coastal areas inBatangRegency sparks an impact that is the incidence of a very high abrasion increase. Approximately, 4.2 ha of the land is susceptible to sea level rise in BatangSub-district, KandemanSub-district, and Subah Sub-district (Kusumawardani, 2013). This study aims to examine the direction of land use development in coastal areas of Batang Regency by utilizingspatial analysis.

\section{Research Methodology}

Research on sustainable coastal resource management in Batang Regency is a research utilizing quantitative descriptive approach This approach is carried out by collecting data obtained from population samples analyzed by statistical methods which then 
the result gets interpreted. According to Sugiyono (2015), quantitative method is referred to as a positivistic method with scientific methodbecause it has fulfilled the rules of science that is concrete / empirical, objective, measurable, rational, and systematic. The analysis is implemented with the support of theories, hypotheses and phenomena that develop at this time. In addition, this studyis also based on parameters that are preparedby using secondary data and primary data.

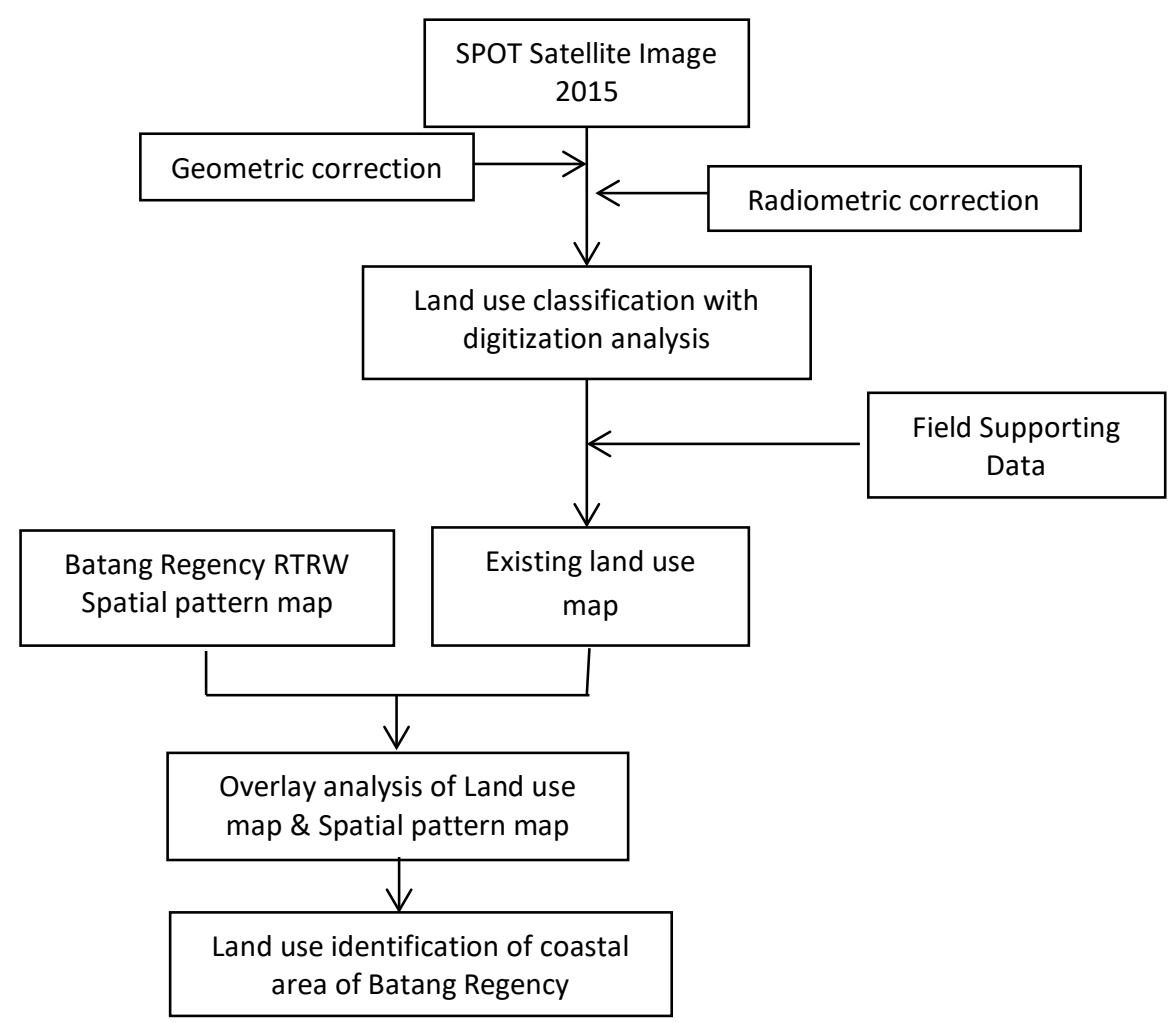

Figure 1. Process Flow of Land Use Identification of Coastal Area in Batang Regency Source: Author's Analysis, 2017

Land use identification is implemented to determine the nonoptimalspatial condition of land in BatangRegencyfor the current development. This analysis is conducted with SPOT satellite image data of 2015, spatial pattern data of BatangRegency, field observation photograph, and other supporting data. The tools include Er-Mapper software, Arc GIS 10.3 software, SPSS software, camera, GPS, stationery, and laptop. The analysis performed in land use identification is Overlay analysis. Overlay analysis is often referred to as overlapping analysis. This analysisutilizessatellite imagery with digitizeon-screen processing to obtain the latest land use of coastal areas of BatangRegency. The preliminary analysis includesgeometric and radiometric correction. This process includesobservation and validation between the processing with the real condition of the field related to land use. The purpose of observation and validation in the field is to ensure the land use that is either optimal or not optimal. It is also supported by the photo of existing conditions and coordinates list. After that, the overlay analysis is conducted between spatial land use and spatialplan map of BatangRegency. From this analysis,the land use thatis either optimal ornonoptimal will show. This study will focus on the land use that has not been optimally 
utilizedin accordance with the spatial planning of BatangRegency. Therefore, it will discover how much land that either has been utilized or has not been utilized.

\section{General Description}

Batang Regency is one of the regencies that have a mixture of geographical situations between the coastal areas, lowland and the mountains. The coastal area of Batang Regency possesses strategic value in the development of the region and the city.Thissituation is due to its locationin the coastal line, and almost half of its sub-districts are in coastal areas. The coastal area of Batang Regency consists of 6 sub-districts which areBatangSub-district, KandemanSub-district, Tulis Sub-district, SubahSub-district, BanyuputihSub-district, and GringsingSub-district. It is in figure 2 as follows:

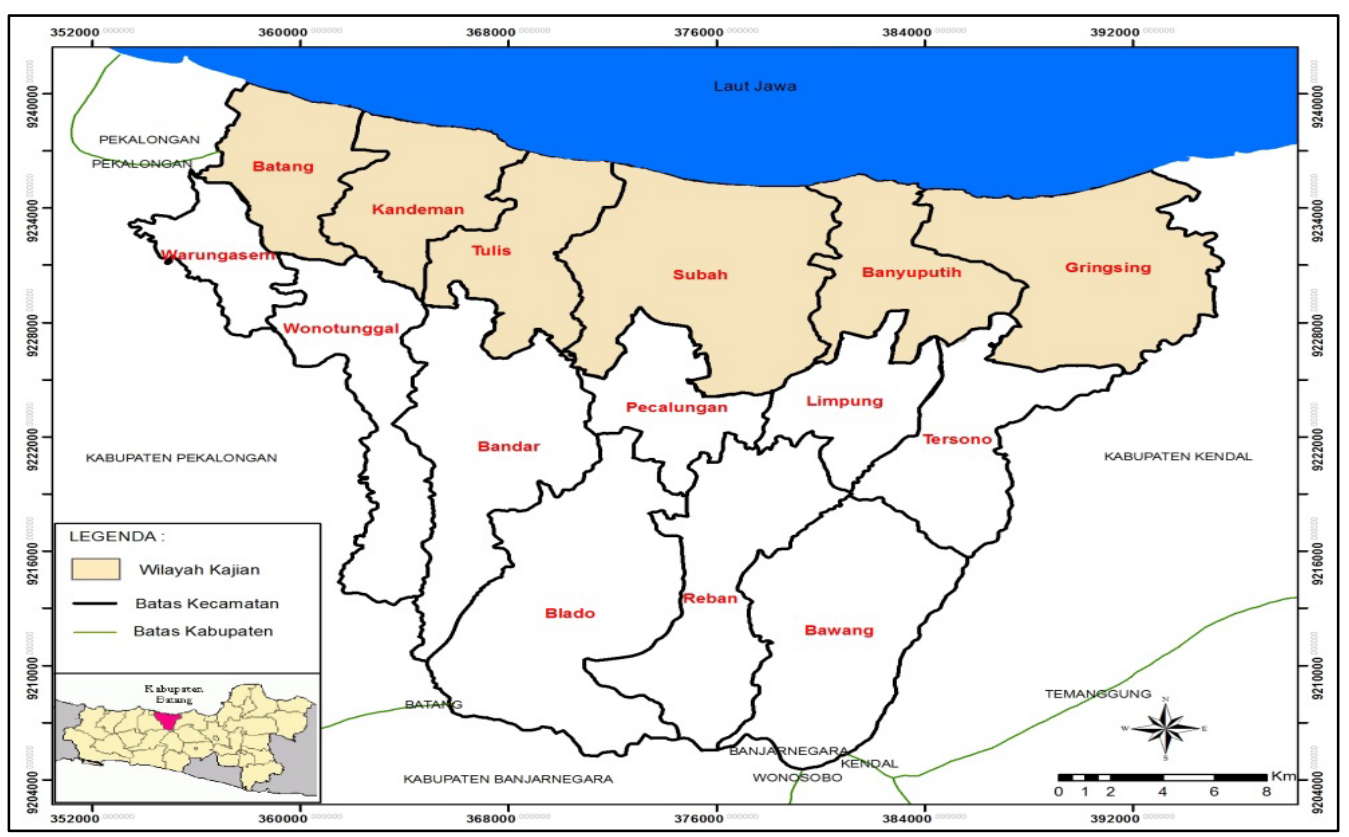

Figure 2. Study Area MAP

Source: Author's Analysis, 2017

\section{Literatuter Review}

Coastal area is a unique region with various complex characteristics. According to Kristiyanti (2016), in the latest international agreement, the coastal areais defined as the transition region between the sea and the land, towards land covering areas that are still affected by sea splash or tidal and towards the sea covering the continental exposure area. The landward boundary includes the administrative boundaries of all coastal villages belonging to the coastal areas. Inadministrative aspect, coastalareais an area that is administratively governed by the upper boundary of the upstream district or city, and towards the sea twelve miles from the coastline for the province or one-third of the twelve miles for the district/city. In planning aspect,coastal area is the area of management planning and focused on issues handling responsibly (Hidayati, 2013). According to Lasabuda (2013), several potentials and advantages of Indonesia's coastal and marine resources are area potential, biological resource potential, mineral and energy resources potential, maritime industry and services potential, marine transportation potential and environmental services, and cultural potential. 
Sustainable development owns a vital role to play in its implementation because there are many principles to implement inproper and orderly manner. Thissituation concerns the interests of all stakeholders with the common goal of creating community welfare. Management of sustainable coastal area is critical. According to Arifin (2004) in Witarsa (2015), co-management combines elements of user community (fishermen group, fishery entrepreneur, etc.) and the government that avoids the overriding dominant role of one party in the management of coastal and marine resources so that aspiration habits in one party can be eliminated. Sustainable development transforms short-term perspectives into long-term perspectives, enriches natural resources that will have economic, social and environmental impacts, and simultaneously removes natural resource degradation and depletion (Salim, 2010). Science and technology can increase the added value of natural resources that can last for a long time.

Local and regional government policies must actively support more effective coastal management through preparing guidelines for coastal resource management, greater community participation and stakeholder engagement in coastal development projects, design and implementation of new monitoring programs (Buono, 2015). Additionally, according to Sale (2014), policies adapted to local and interim social-ecological contexts should consider external inputs and processes from cultures, businesses, laws, public opinions, and other considerations. Policies for coastal zone management and planning should be able to promote effective and balanced conservation and sustainable development, within the sphere of integrated coastal management (Cicin-Sain and Knecht, 1996). Land use policy using spatial analysis becomes an alternative in supporting integrated coastal area management. According to Munroe and Muller (2007), land use change is a complex phenomenon which reflects the interaction between humans and their environment. In this case, thehumanis as subject to carry out management and environmentis amaterialobjectfor planning and development. In addition, coastal land use planning considers land capability for specific purposes to maintain sustainable living environments (Panem, 2006).

\section{Results And Discussion}

\subsection{Satellite Management of Satelite Coastal Region of Batang Regency}

Land use evaluation of coastal areas inBatang Regency utilizes spatial analysis by the assistance of Geographic Information System (GIS). The image processing is the first to performby radiometric correction and geometric correction, thenthedigitization of land use in coastal area follows suit. The corrected SPOT satellite image will bevisibly better than the satellite image which is yet to receive to those two corrections. The superiority ofgeometricallycorrectedimage is that thesatellite image can match the imageof world coordinates, while radiometric correction provides a more precise visual image quality so that the use of satellite imagery itself can be more optimal. After correcting the satellite images, the next step is a digitization process to observe land use in the coastal area of Batang Regency. The results of image processing analysis show clear images of the existing land use in coastal areas such as settlements, forests, rice fields, and others. The second result of the correction to the SPOT satellite image is as shown in Figure 3. 


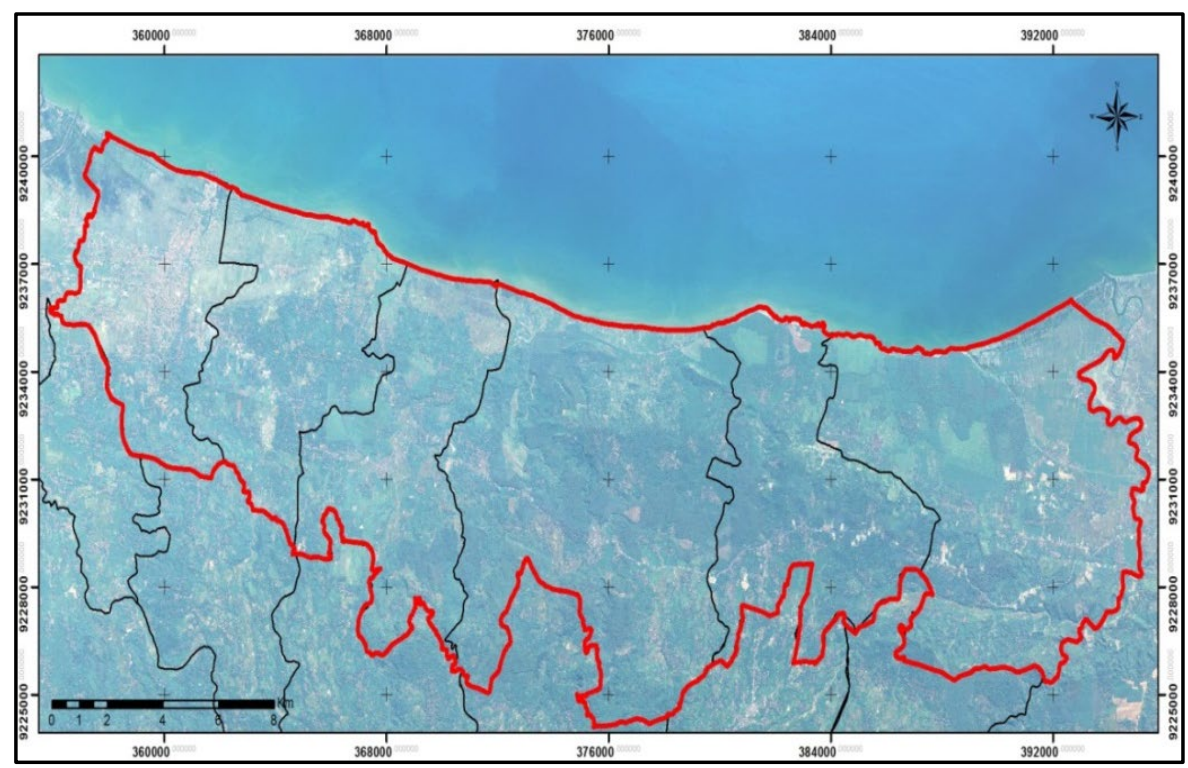

Figure 3. Improved Satellite Image Result Source: Author's Analysis, 2017

\subsection{Image Classification}

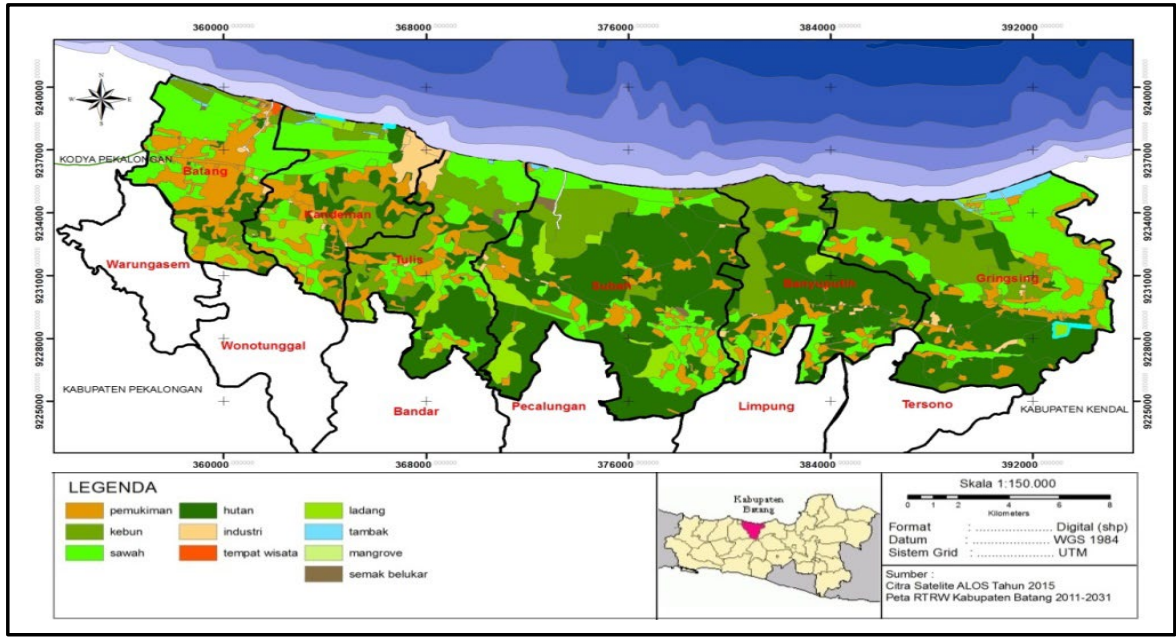

Figure 4. Classification Map of Land Use of Coastal Area of Batang Regency Source: Author's Analysis, 2017

Image classification is carried out by using acorrected image which is either by radiometric correction or geometric correction. It aims to reduce errors of interpretation that often occur in the stages of the classification process. Classification stages implementonscreen digitization technique. This technique shows directly on the screen by classifying existing land use on the map or satellite. Satellite image analysis resultby using land use digitization technique isorganized into ten types that represent all kinds of land use in the coastal area of Batang Regency. Those ten types of land use classification are settlements, rice fields, forests, gardens, fields, tourist sites, industries, ponds, mangroves and shrubs. 


\subsection{Accuracy Test of Classification Results}

Accuracy test is one way to testclassification result that has been performed in determining eligibility to proceed to the next analysis. This accuracy test involves location surveys supported by photos. Some of the existing land use sample points will be compared with the classification result. There are 500 coordinate points of land use location sampling spread throughout the coastal area of Batang Regency. This accuracy test will utilize descriptive statistical method through Cohen's Kappa coefficient test which aims to discover the consistency level of land use classification with thereal condition in the field. Determination of location sample points based on geographical area is taken at random so that it covers the entire study area. The process includes overlay between land use classification map with sample point in the whole coastal area of Batang Regency

The overlay result between the whole survey sample points with the classification of land use generates some correction of land use recorded in thereal condition in the field. After that, acoefficienttest of Cohen's Kappa is performed to find out the valuein consistency of existing land use process with survey point of coastal area in Batang Regency. The results of the coefficient test of Cohen's Kappa show the coefficient of land use classification value of 0.903 with a significance value of 0,000 , way below 0.05. According to Anderson (1976) in Farda \& Khoiriah (2012), the value of Cohen's Kappa coefficient above 0.85 (85\%) for the classification of land use is still acceptable to the actual condition of current land use. Therefore, the classification result can be the base for analysis and interpretation process ofexisting land use in the coastal area of Batang Regency. Based on the tabulation test of land use classification, there are some partial errors occur between objects as forest, rice fields, fields, gardens and constructed lands such as industry, settlement, and others. Differences of two years affect the classification of land use in the coastal area of BatangRegency, but most of the classification of land use is still relevant after the test of Cohen's Kappacoefficiency.

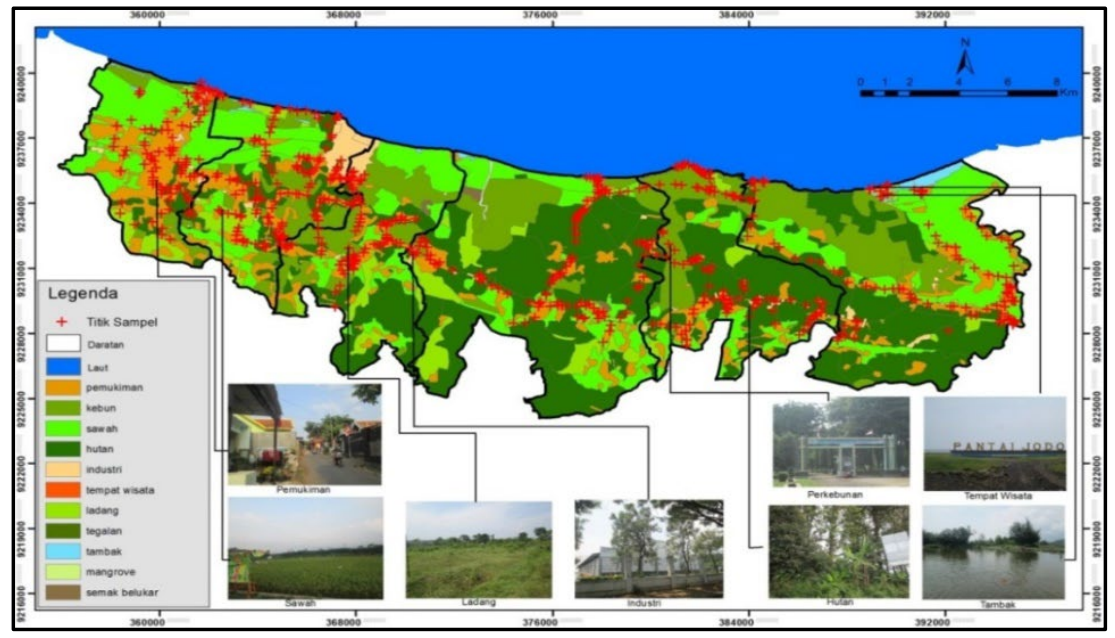

Figure 5. Map Of Sample Points Of Land Use Of Coastal Area Of Batang Regency Source: Author analysis, 2017

\subsection{Analysis of land use in coastal area of Batang Regency}

Analysis of land use in the coastal area of Batang Regency is conducted to determine areas that have the potential for coastal resources development that has been and has not been utilized. Optimal land use will have an impact on future coastal developments and sustainability of the coastal area. 
Table 1. Comparison of Existing Land Use Area With Spatial Plan of 2011-2031 Batang Regency

EXISTING LAND USE

\begin{tabular}{lrrlrr}
\multicolumn{1}{c}{ Land Use } & Area (ha) & Percentage & LandUse & Area (ha) & Percentage \\
Settlements & $4.959,946$ & 15,381 & Settlements & $8.745,730$ & 27,067 \\
Rice fields & $7.087,174$ & 21,977 & Rice fields & $5.543,820$ & 17,158 \\
Forest & $11.253,600$ & 34,898 & Forest & $4.437,220$ & 13,733 \\
Garden & $5.945,321$ & 18,437 & Garden & $8.293,730$ & 25,668 \\
Field & $2.032,352$ & 6,302 & Field & $1.515,720$ & 4,691 \\
Tourist sites & 47,039 & 0,146 & Tourist sites & 136,778 & 0,423 \\
Industry & 587,567 & 1,822 & Industry & $1.199,310$ & 3,712 \\
Pond & 209,849 & 0,651 & Pond & 636,126 & 1,969 \\
Mangrove & 1,108 & 0,003 & Border & $1.007,100$ & 3,117 \\
Shrubs & 123,471 & 0,383 & Others & 795,411 & 2,462
\end{tabular}

Source: Author's analysis, 2017

The result of overallevaluation of existing land use with pattern allotment of coastal area in Batang Regency which is suitable category equals to $56,32 \%$ and not yet suitable equals to $43,68 \%$. Based on the evaluation results, there are two concluded possibilities. First, there is stillland use that has not been appropriately utilized according to allotment of coastal area pattern of Batang Regency. The use of the land in question should be the spatial pattern for either residential area which is still in the form of rice field or industrial area allotment which is still in the form of bushes and gardens. Therefore, there is stillenormous potential of thecoastalarea to be developed. The second is the land use that is not suitable with the designation of the existing spatial pattern in the coastal area or not yet to be maximally supervised by the government in enforcing the regulation of Batang Regency Spatial Plan such as the existing land use for settlement which should have been reserved for thecoastal border. Thisconcern should be a joint evaluation of the community, government, and the private sector to be able to comply with existing Spatial Plan regulations in land use allocation in the coastal area ofBatang Regency. The land use evaluation map is in Figure 6 as follows. 


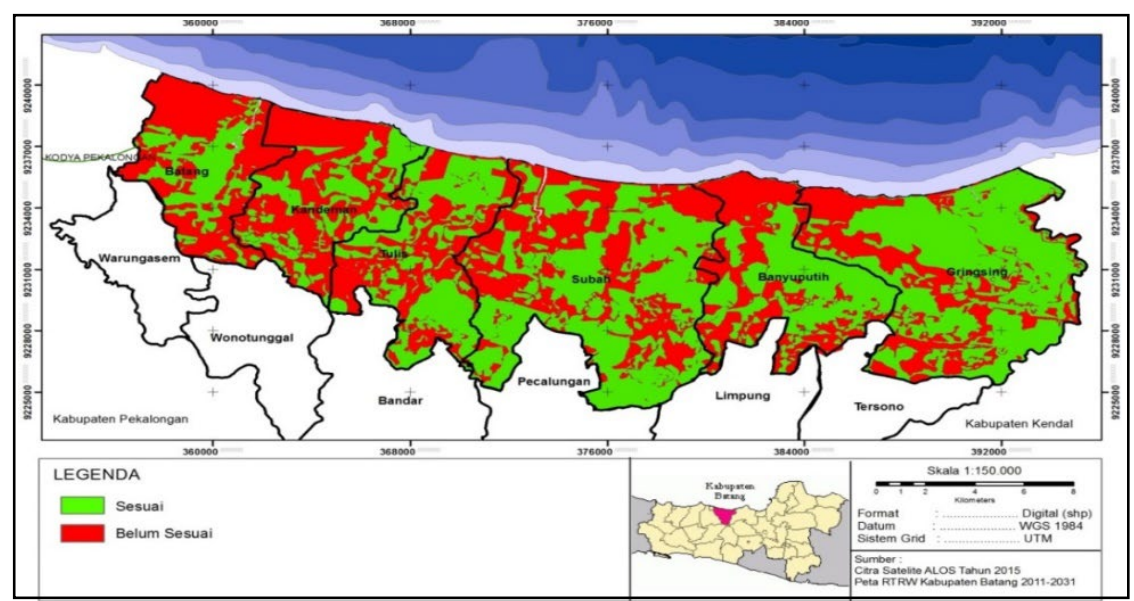

Figure 6. Land Use Evaluation Map

Source: Author's analysis, 2017

Batang Sub-district possesses landin accordance withSpatial Plan year 2011-2031 of thecoastal area of 1.214,03 ha and theunsuitable land of 2.220,51 ha. The area that does not suit the Spatial Plan is greater than the corresponding one. Thissituation is because,in most of the sub-districts, the existing land use in the form of rice fields is actually designated for spatial patterns of settlements so that residential areas inBatangSub-district can still be developed. Most of the spatial pattern designationforBatangSub-district is for urban residential areas which makes development potential for settlement quite high. In addition, accessibility in Batang Sub-district is quite convenient to create it as Center for Local Activities/Pusat Kegiatan Lokal (PKL). Aside of Batang Sub-district, settlement designation is also located in KandemanSub-district. Tulis Sub-districtownsproper use of land compared to Batang and Kandeman Sub-districts. TulisSub-district's suitable area is 2.452,98 ha while theunsuitable area is $2.055,80$ ha. Areas that have not been suitable for most of the designation for border areasare currently utilized for fields and rice fields. Other than that, in the existing situation, the designated land for industry is still in the form of forest and garden. The evaluation is in Table 2 .

Table 2. Evaluation Result of Existing Land Use With Spatial Plan

\begin{tabular}{lrr} 
Sub-district & \multicolumn{1}{l}{ Suitable } & \multicolumn{1}{c}{ Unsuitable } \\
Batang & $1.214,03$ & $2.220,51$ \\
Kandeman & $1.565,02$ & $2.610,65$ \\
Tulis & $2.452,98$ & $2.055,80$ \\
Subah & $5.381,89$ & $2.970,28$ \\
Banyuputih & $2.314,61$ & $2.127,89$ \\
Gringsing & $5.202,12$ & $2.074,31$ \\
Total & $18.130,65$ & $14.059,44$
\end{tabular}

Source: Author's analysis, 2017 
Most of Banyuputih Sub-district area is designated for plantation area, industrial estate, and residential area. From the evaluation result of land use, appropriate area in accordance with the spatial pattern is $2.314,61$ ha, and unsuitable area equals to $2.127,89$ ha. It can be seen in Figure 4.7 that the unsuitableland use is located in the north of BanyuputihSub-district because the allocation for theindustrial estate is still in the form of rice field, garden and settlement. GringsingSub-district has more suitable existing land use than unsuitablearea because the suitable area is 5.202,12 ha while unsuitable area is $2.074,31$ ha. Almost all of the land use inGringsing district is in accordance with the designation of existing spatial patterns in coastal areas of Batang Regency. There are someunsuitable areas in the northern part of GringsingSub-district because it should be intended for industrial areaswhile the existing land use is still as gardens, forests, fields, and fields so that there are still areas that have not been optimally utilized.

Table 3. Result of Evaluation of Land Use Which Not Yet Suitable in Coastal of Batang Regency Based on Space Pattern

\begin{tabular}{|l|l|r|r|r|r|r|r|}
\hline \multirow{2}{*}{ No } & \multirow{2}{*}{ LandUse } & \multicolumn{7}{|c|}{ SUB-DISTRICT } \\
\cline { 3 - 8 } & & Batang & Kandeman & \multicolumn{1}{l|}{ Tulis } & Subah & Banyuputih & Gringsing \\
\hline 1 & Settlements & 1870.67 & 1697.28 & 443.77 & 486.73 & 482.68 & 439.44 \\
\hline 2 & Rice fields & 272.76 & 350.71 & 436.14 & 442.29 & 386.27 & 374.01 \\
\hline 3 & Forest & 0.00 & 0.00 & 106.22 & 559.10 & 198.99 & 81.61 \\
\hline 4 & Garden & 23.54 & 253.64 & 420.95 & 687.90 & 398.09 & 528.15 \\
\hline 5 & Field & 1.39 & 92.86 & 226.40 & 284.19 & 56.81 & 173.38 \\
\hline 6 & Industry & 0.00 & 19.26 & 153.26 & 278.27 & 327.73 & 292.63 \\
\hline 7 & Pond & 0.00 & 0.00 & 0.00 & 0.00 & 194.24 & 0.00 \\
\hline 8 & Tourist sites & 0.00 & 134.64 & 0.00 & 0.00 & 0.00 & 0.00 \\
\hline 9 & Border & 46.53 & 44.31 & 219.31 & 216.05 & 83.07 & 185.08 \\
\hline 10 & Shrubs & 5.61 & 17.95 & 49.74 & 15.76 & 62.58 & 160.67 \\
\hline
\end{tabular}

Source: Author's analysis, 2017

The evaluation result of land use that is not suitable based on the spatial pattern according to each sub-district resulted in the conclusion that most of the sub-districts in the coastal area of BatangRegency still tend to be developed for the designation of settlement. Batang and Kandeman Sub-districts have the most extensivearea compared with other districts, namely 1870,67 ha and 1697,28 harespectively. The existing land use for paddy fields is also mostly not suitable ranging from 270 ha to 450 ha in each sub-district. The unsuitable existing land use for forest is mainly in Subah Sub-district including the land useof garden and fields. While the designation of industry that is notsuitable are concentrated in three Sub-districts which areSubahSub-district, BanyuputihSub-district, and GringsingSub-district. Unsuitable land useas pond is mostly in BanyuputihSub-district which equals to 194,4 ha. The landuse for tourist attractions can still be developed in KandemanSub-district with an area of 134,64 ha. The land use for irrelevant border exists in all sub-districts with the highest area in Tulis Sub-district of 219,31 ha. The highest unsuitable land use for shrubs is in Gringsing district with an area of 160,67 ha. From the results of the evaluation of land use, there is still the need for the development of designation of settlements, industries, ponds, and tourist attractions in several sub-districts. In addition, there is a need for sustainable use of wetland, forests, fields, gardens, and border areas. 


\section{Conclusion}

Evaluation analysis of existing land use with the coastal area pattern of Batang Regency possesses two categories which are suitable category and unsuitable category. Based on spatial analysis from the land use evaluation as a whole, Batang Regencyis discovered to possess suitable category equals to $18.139,65$ ha with the percentage of $56,32 \%$ and unsuitable category equals to $14.059,44$ ha with the percentage of $43,68 \%$. BatangSubdistrict's suitable category is 1.214,03 ha, while the unsuitable category equals to 2.220,51 ha. Kandeman Sub-district's suitable category is 1.565,02 ha, while the unsuitable category equals to 2.610,65 ha. Tulis Sub-district's suitable category is 2.452,98 ha, while the unsuitablecategory equals to $2.055,80$ ha. SubahSub-district'ssuitable category is $5.381,89$ ha, while the unsuitablecategory equals to $2.970,28$ ha. Banyuputih Subdistrict'ssuitablecategory is $2.314,61$ ha, while the unsuitablecategory equals to $2.127,89$ ha. Gringsing Sub-district's suitable category is 5.202,12 ha, while the unsuitable category equals to 2.074,31 ha.The conclusion of land use planning development for Batang and Kandeman Sub-districts is that there is still a lot of land for residential development. Designation for Subah Sub-district is fisheries development while Banyuputih Sub-district and GringsingSub-district are for industrial development.

\section{References}

Badan Pusat Statistik Kabupaten Batang. 2016. Statistik Daerah Kabupaten Batang tahun 2016. Bengen, D. G. 2010. Ekosistem dan Sumber daya Pesisir dan Laut Serta Pengelolan Secara Terpadu dan Berkelanjutan. In Pengelolaan Wilayah Pesisir Terpadu. Bogor: Pusat Kajian Sumber daya Pesisir dan Lautan, Fakultas Perikanan dan Ilmu Kelautan. IPB.Bogor

Bramati, M. C., F. Musella, and G. Alleva. 2014. "What Drives Environmental Conflicts in Coastal Areas? An Econometric Approach." Ocean and Coastal Management 101 (PB). Elsevier Ltd: 63-78. doi:10.1016/j.ocecoaman.2014.06.012.

Buono, Fabrizia, Stefano Soriani, Monica Camuffo, Marco Tonino, and Andrea Bordin. 2015. "Corrigendum to 'The Difficult Road to Integrated Coastal Zone Management Implementation in Italy: Evidences from the Italian North Adriatic Regions' [Ocean Coast. Manag. 114 (2015) 21-31]." Ocean and Coastal Management 116. Elsevier Ltd: 534. doi:10.1016/j.ocecoaman. 2015.08.001.

Burrough, P. A., 1986. Principles of Geographycal Information System for Land Resources Assesment. Monograph on Soil and Resources Surveys, No. 12. Oxford Science Publication.

Cicin-sain, Biliana, Robert W Knecht, and Gregory W Fisk. 1996. "Growth in Capacity for Integrated Coastal Management since UNCED : An International Perspective” 29 (June 1992): 93-123.

Dahuri,R., J. Rais, S.P.Gintingdan M.J. Sitepu. 2003. Pengelolaan Sumberdaya Pesisir dan Lautan Secara Terpadu. PT. Prdnya Paramita, Jakarta.

Farda, N.M., \& Khoiriah, I.F. (2012). Perbandungan Akurasi Klasifikasi Penutupan Lahan Hasil Penggabungan Citra Alos Avnir-2 dan Alos Palsar Pada Polarisasi Berbeda Dengan Transformasi Wavelet. Jurnal Bumi Indonesia, 1.

Hidayati, Asih. 2013. Pengelolaan Wilayah Pesisir Berbasis Daya Dukung Lingkungan Dan Partisipasi Masyarakat Di Kabupaten Batang:Tesis, Program Studi Ilmu Perencanaan Wilayah, Institut Pertanian Bogor, Bogor.

Kristiyanti, Mariana. 2016. Pemberdayaan Masyarakat Pesisir Pantai Melalui Pendekatan ICZM (Integrated Coastal Zone Management). Prosiding Seminar Nasional Multi DisiplinIlmu\& Call For Papers Unisbank (Sendi_U) Ke-2 Tahun 2016. 
Kusumawardani, Cintya. 2013. Kerentanan Pantai Terhadap Kenaikan Paras Laut di Sepanjang Pantai Kabupaten Batang, Jawa Tengah. Skripsi. Studi Ilmu dan Teknologi Kelautan. Institut Pertanian Bogor, Bogor.

Lasabuda R. 2013. Pembangunan Wilayah Pesisir dan Lautan Dalam Perspektif Negara Kepulauan Republik Indonesia.TinjauanTeoritis. Jurnal Ilmiah Platax. 1(2): 92-101. London.

Munroe, D.K., and Muller, D. 2007. "Issues in spatially explicit statistical land-use/cover change (LUCC) models : Examples from western Honduras and the Central Highlands of Vietnam", Land Use danPolicy Vol. 24.(521-530), Elsevier

Peraturan Daerah no 07 tahun 2011 tentang Rencana Tata Ruang Wilayah Kabupaten Batang Tahun 2011-2031.

Peraturan Menteri Kelautan Dan Perikanan Republik Indonesia Nomor 23/Permen$\mathrm{Kp} / 2016$ tentang perencanaan pengelolaan wilayah pesisir dan pulau-pulau kecil.

Pinem, Ferrari. 2006. Spatial Multi Criteria Decision Making For Coastal Land Management (A Case Study In Maros, South Sulawesi). Tesis. Master of Science in Information Technology For Natural Resources Management. Bogor Agricultural University. Bogor

Riza, A.I. 2016. Aplikasi Sistem Informasi Geografis dalam Penentuan Kesesuaian Lokasi Perikanan Budidaya Tambak Ramah Lingkungan di Kabupaten Batang, Jawa Tengah. Jurnal Riset, Inovasidan Teknologi Kabupaten Batang. Juli - Desember 2016.Vol.1 (1):17-31.

Sale, Peter F., Tundi Agardy, Cameron H. Ainsworth, Blake E. Feist, Johann D. Bell, Patrick Christie, Ove Hoegh-Guldberg, et al. 2014. "Transforming Management of Tropical Coastal Seas to Cope with Challenges of the 21 st Century." Marine Pollution Bulletin 85 (1). Elsevier Ltd: 8-23. doi:10.1016/j.marpolbul.2014.06.005.

Salim E. 2010. Pembangunan Berkelanjutan Perandan Kontribusi Emil Salim. Azis IJ, Napitupulu LM, Patunru AA, Resosudarmo BP, editor.Jakarta (ID):Kepustakaan Populer Gramedia.

Sugiyono. 2015. Metodologi penelitian Pendidikan (Pendekatan Kuantitatif, Kualitatifdan RED). Bandung. Alfabeta.

Undang-undang Republik Indonesia no 1 Tahun 2014 tentang Pengelolaan Wilayah PesisirdanPulau-Pulau Kecil.

Witarsa. 2015. Model Pengembangan Ekonomi Masyarakat Pesisir Berbasis Co-Management Sumber daya Perikanan Di Kabupaten Pontianak. Prosiding Seminar Nasional 9 Mei 2015 